\title{
Need for growing non-Bt cotton refugia to overcome $B t$ resistance problem in targeted larvae of the cotton bollworms, Helicoverpa armigera and Pectinophora gossypiella
}

\author{
Muhammad Rafiq Shahid', Muhammad Farooq ${ }^{1,2}$, Muhammad Shakee ${ }^{3^{*}}$ (D), Misbah Ashraf ${ }^{4}$, Zia Ullah Zia ${ }^{1}$,
} Saghir Ahmad ${ }^{1}$ and Abid Mahmood ${ }^{5}$

\begin{abstract}
Background: The effectiveness of Bacillus thuringiensis $(B t)$ cotton against target arthropod larvae is decreasing day by day. The comparative effect of Bt expression among Bt cotton varieties and different plant parts was observed against the cotton bollworms: Helicoverpa armigera and Pectinophora gossypiella larvae.

Results: In the present study, larval mortality of $\mathrm{H}$. armigera was higher than $P$. gossypiella among selected $B t$ cultivars. Median lethal concentration $\left(\mathrm{LC}_{50}\right)$ values were 8.91, 13.4, 14.0, and 36.4 for $P$. gossypiella, while 5.91, 4.04, 2.37, and 8.26 for $\mathrm{H}$. armigera of FH-142, MNH-886, IR-3701, and FH-Lalazar, respectively. These values depicted that P. gossypiella had more Bt resistance problem than $\mathrm{H}$. armigera larvae. The host range of both targeted insect larvae was different from each other due to the polyphagous feeding nature of the larvae of $\mathrm{H}$. armigera that feed on different host plants, but $P$. gossypiella attacked only cotton with monophagous feeding habit. It was also notable from results that $B t$ expression in reproductive parts where the attacked pink bollworm was lower than the American bollworm, so the former had the maximum chance of resistance due to repeated exposure to $B t$.

Conclusions: It was concluded that farmers be advised to follow the practice of growing non-Bt as a refuge crop to reduce the problem of $B t$ resistance in the target arthropod species.
\end{abstract}

Keywords: CryIAC, ELISA, Insecticidal protein, Herbivory behavior, Lepidopterous larvae, Refuge crop

\section{Background}

Transgenic crops are the most widespread technology of proteintic engineering due to their effective control against lepidopterous arthropods (Wu et al. 2005). The range of $B t$ crops planted worldwide has increased from 1.7 million hectares to 185.1 million hectares since 1996 to 2016, respectively (Huang et al. 2017). Cry1Ac

\footnotetext{
* Correspondence: faizaneabiwaqas@scau.edu.cn

${ }^{3}$ Key Laboratory of Bio-Pesticide Innovation and Application of Guangdong Province, College of Plant Protection, South China Agricultural University,

Guangzhou, China

Full list of author information is available at the end of the article
}

insecticidal protein produced by $\mathrm{Cry} 1 \mathrm{Ac}$ protein proved to be very lethal against lepidopterous insect pests. Due to various environmental and socio-economic benefits, $B t$ cotton initially available in the USA started growing in different parts of the world afterward (Sansinenea 2019).

Insecticidal crystalline protein intensities and their effectiveness depend upon the cultivar's potential to produce $B t$ protein, its growth stage, and plant part used (Olsen et al. 2005 and Wan et al. 2012). It also influences the biological parameters of feeding insect species because the life parameters of herbivores depend on the 
stage of larvae and the quantity of CrylAc ingested by it (Stewart et al., 2001).

Cultivation of non- $B t$ refuge is ignored in Pakistan; therefore, frequency of cases of evolution of $B t$ resistance is very high. The lepidopterous larvae of Helicoverpa armigera (Hb.) and Pectinophora gossypiella (Saund.) are the main insect pests that adversely affect crop productivity by feeding directly on reproductive parts of cotton. Due to the polyphagous feeding existence, $H$. armigera continues its activity in different host plants compared to the monophagous P. gossypiella larvae (Pogue 2004). H. armigera larvae feed on leaves, buds, and fruit sections, causing damage to the vegetative and reproductive stages of various crop species other than cotton (Pratissoli et al. 2015). P. gossypiella larvae feed only on the bolls internally (Mapuranga et al., 2015). Owing to continuous cultivation of $B t$ cotton and restricted feeding only on cotton, the field population of monophagous larvae has more chances of evolved resistance against the Cry1Ac protein (Tabashnik et al., 2013; Jin et al., 2015 and Sansinenea 2019). In this way, P. gossypiella seems to become a more damaging insect pest of cotton than the polyphagous $H$. armigera (Dhurua and Gujar, 2011).

In previous studies, Cry1Ac concentration was determined in leaf parts, and its effect on only single herbivorous insect pest larvae was observed by Kranthi et al. (2005). In the present research, it was determined in all vegetative and reproductive parts of the plant as well as its effect on larvae of two notorious insect pests. In Pakistan, it is also the first field report on the importance of refuge crops to mitigate $B t$ resistance problem in the targetted larvae.

\section{Methods}

The present study was carried out during the cotton growing season 2018-2019. The commercially available material for proteinral sowing consisted of five cultivars of cotton (Gossypium hirsutum L.) including $4 \mathrm{Bt}$ possessing Cry1Ac protein, i.e., FH-142, MNH-886, IR-3701, FH-Lalazar, and one non- $B t$ cultivar, i.e., FH-4243 kept as a control for comparison throughout the experimentation. The seeds were sown on 10 May 2018 on beds, following the dibbling method (placement of seed in holes and covering with sand on raised rows). Each variety comprised of 6 rows with row to row $7.5-\mathrm{cm}$ width and $75 \mathrm{~cm}$ length, so plot size was $3375 \mathrm{~cm}^{2}$ for each variety wise and the total plot size of one replication of all selected 5 varieties (both $B t$ and non-Bt) comprised $16,875 \mathrm{~cm}^{2}$. The experiment was laid out following Randomized Complete Block Design (RCBD) with three replications.

\section{Procedure of $B t$ testing}

Kanamycin application on leaves is one of the methods that can be used to screen out transgenic and nontransgenic plants. At 30 days after sowing, Kanamycin's $1500 \mathrm{ppm}$ solution was applied to differentiate $B t$ and non- $B t$ plants. Kanamycin affected photosynthesis at the application surface of the non- $B t$ leaves but neomycin phosphotransferase protein in transgenic plants degrades the effect of kanamycin so leaves remained healthier (Duan et al. 2009 and Shahid et al. 2017). For further confirmation with ELISA, 5 representative plants from each cultivar were selected randomly and tagged. Upper, middle, lower leaves, leaf pedicel, root, and stem from $B t$ plants of each cultivar were taken to quantify Cry1Ac protein concentration at $30,60,90$, and 120 days after sowing; however, flowers were taken from the 120 days old plants of each variety. The number of the days taken to the first flower differed with respect to selected cultivars of cotton depending upon the earliness starting from 35 to 50 days (Wrather et al., 2008). Flower initiation started from 35 to 50 days depending upon the earliness behavior of the selected cultivars; therefore, $B t$ quantification was done after 60 days after sowing (Shah et al. 2017), when flowers were available on all selected genotypes. Sandwich-enzyme linked immunosorbent assay: quantification of CrylAc protein ( $B t$ toxin) in all selected parts of each variety was carried out, following sandwich-ELISA ELISA as the instructions of Envirologix Inc. USA (manufacturer). Optical density reading was recorded on ELISA plate reader at $450 \mathrm{~nm}$. Bt toxin level $(\mu \mathrm{g} / \mathrm{g})$ was calculated and compared to standard $(1.5 \mu \mathrm{g} / \mathrm{g}$ recommended by EPA-USA) and according to the procedure, followed Ali et al. (2018).

\section{Insect culture}

In order to obtain a susceptible generation, 400 larvae (3rd instar and above) of both species were collected from Gossypium arborium (locally called Desi cotton). The reason behind the selection of G. arborium was that due to species difference between G. arborium and hirsutum, it does not have a chance of pollen-mediated gene flow of Cry1Ac to G. arborium and ultimately to larval population of both target species. Collected population was kept in glass Petri dishes and shifted to the laboratory. To overcome the fungal problem, fieldcollected population was washed with sodium hypochlorite $0.05 \%$ solution. It was separated into a single specimen due to cannibalism at larval instars of lepidopteran, especially $H$. armigera. Both species were provided by food for rearing under laboratory maintained at $28 \pm$ $2{ }^{\circ} \mathrm{C}$ and $65 \pm 5 \% \mathrm{RH}$. After adult emergence from pupae, both male and female moths were released for egg-laying on small cotton plants into separate cages. 
Eggs were incubated for hatching and the neonates were used for further experimentation.

\section{Determination of mortality of target insect species by Bioassays technique}

A total of $50 \mathrm{~F}_{1}$ neonate of $H$. armigera and $P$. gossypiella larvae of uniform size and age were obtained from the culture, released individually into the flowers of 5 plants of each selected variety, and covered with the help of muslin cloth under semi-natural field condition to avoid their escape. Percentage of mortality of both insect pest species larvae was recorded on all tested transgenic cultivars of cotton in each replication and it was compared to FH-4243 (non-Bt cultivar, kept as control, to avoid the chance of error due to the natural mortality of the targeted larvae). Mortality was recorded, using the formula given as under:

$$
\text { Mortality } \%=\frac{\text { Dead larvae }}{\text { Total larvae released }} \times 100
$$

\section{Statistical analysis}

Mortality parameter of $H$. armigera and $P$. gossypiella was correlated by $B t$ toxin quantification of $\mathrm{Cry} 1 \mathrm{AC}$ among selected cultivars determined in different parts and at different instars. Data were analyzed using ANOVA techniques through computer-operated Statistica package 5.5 and means were compared using Tukey's HSD test for significance. Sigmaplot 12.5 package was used for graphical presentation of results subjected to Probit analysis for resistance monitoring by using computer-operated Polo plus statistical software package.

\section{Results}

Expression of Cry1Ac among different cultivars

Cry1Ac concentration was quantified from the top, middle, lower leaves, and leaf pedicel of the selected cultivars. Cry $1 A c$ concentration was maximum in the top leaves of IR-3701 $(3.39 \mu \mathrm{g} / \mathrm{g})$, followed by $\mathrm{FH}-142$ $(2.97 \mu \mathrm{g} / \mathrm{g})$ and FH-Lalazar $(2.5 \mu \mathrm{g} / \mathrm{g})$. In the middle leaves, concentration was maximum in IR3701 and MNH-886 $(2.91 \mu \mathrm{g} / \mathrm{g})$, followed by FH-Lalazar $(2.17 \mu \mathrm{g} /$ g). In lower leaves also, the concentration was high in IR-3701 $(1.62 \mu \mathrm{g} / \mathrm{g})$, followed by FH-Lalazar $(1.6 \mu \mathrm{g} / \mathrm{g})$ and $\mathrm{FH}-142(1.32 \mu \mathrm{g} / \mathrm{g})$. However, in leaf petiole, it was the maximum in MNH-886 $(0.85 \mu \mathrm{g} / \mathrm{g})$, followed by IR$3701(0.3 \mu \mathrm{g} / \mathrm{g})$ and FH-142 (0.2 $\mu \mathrm{g} / \mathrm{g})$ (Fig. 1).

In pedicle, the highest $B t$ toxin level of $C r y 1 A c$ protein was quantified in IR-3701 $(1.5 \mu \mathrm{g} / \mathrm{g})$, followed by FH-142 $(0.87 \mu \mathrm{g} / \mathrm{g}), \quad \mathrm{MNH}-886(0.39 \mu \mathrm{g} / \mathrm{g})$ and FH-Lalazar $(0.31 \mu \mathrm{g} / \mathrm{g})$ (Fig. 1). In sepals, the highest values of Cry1Ac proteins were recorded in IR-3701 $(0.8 \mu \mathrm{g} / \mathrm{g})$, followed by FH-Lalazar $(0.4 \mu \mathrm{g} / \mathrm{g}), \mathrm{MNH}-886(0.36 \mu \mathrm{g} / \mathrm{g})$, and $\mathrm{FH}-142(0.01 \mu \mathrm{g} / \mathrm{g})$. In petals, the highest concentration of $B t$ toxin Cry1Ac was recorded in IR-3701 (0.5 $\mu \mathrm{g} /$ g), followed by MNH-886 $(0.48 \mu \mathrm{g} / \mathrm{g})$, FH-Lalazar $(0.2 \mu \mathrm{g} / \mathrm{g})$, and FH-142 $(0.13 \mu \mathrm{g} / \mathrm{g})$. Pollens had the highest level of Cry1Ac proteinin FH-Lalazar $(1.8 \mu \mathrm{g} / \mathrm{g})$, followed by IR-3701 $(1.1 \mu \mathrm{g} / \mathrm{g}), \mathrm{FH}-142(0.73 \mu \mathrm{g} / \mathrm{g})$, and MNH-886 (0.4 $\mu \mathrm{g} / \mathrm{g})$ (Fig. 1). Stigmaa had the highest

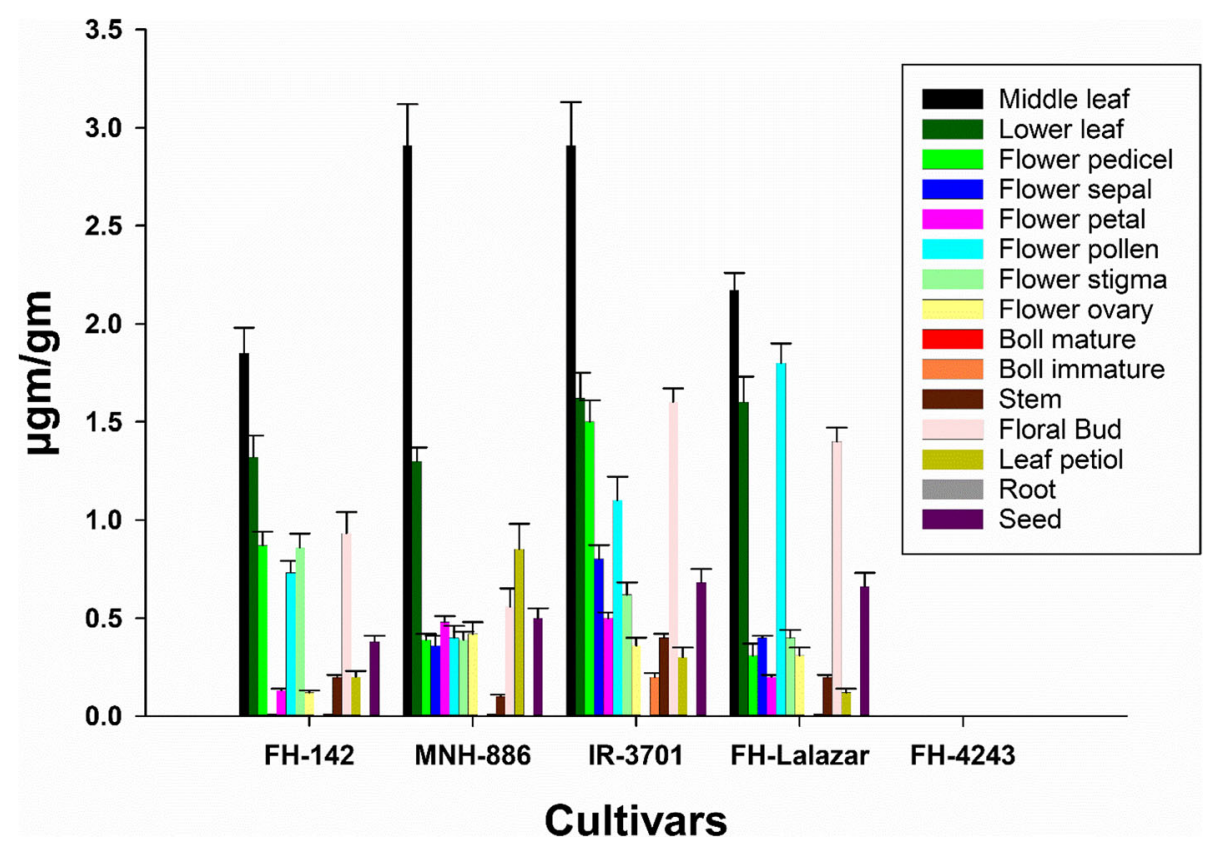

Fig. 1 Bacillus thuringiensis expression of CrylAc ( $\mu \mathrm{g} / \mathrm{g}$ of fresh wt.) in different parts of the plant 
level of Cry1Ac proteinin $\mathrm{FH}-142(0.86 \mu \mathrm{g} / \mathrm{g})$, followed by IR-3701 $(0.62 \mu \mathrm{g} / \mathrm{g})$, FH-Lalazar $(0.4 \mu \mathrm{g} / \mathrm{g})$, and MNH-886 $(0.39 \mu \mathrm{g} / \mathrm{g})$. In the ovary, the highest concentration of $B t$ toxin was found in MNH-886 $(0.42 \mu \mathrm{g} / \mathrm{g})$, followed by IR-3701 $(0.36 \mu \mathrm{g} / \mathrm{g})$, FH-Lalazar $(0.31 \mu \mathrm{g} / \mathrm{g})$, and $\mathrm{FH}-142(0.12 \mu \mathrm{g} / \mathrm{g})$. In floral buds, the highest level of Cry1Ac protein was recorded in IR-3701 $(1.6 \mu \mathrm{g} / \mathrm{g})$, FH-Lalazar $(1.4 \mu \mathrm{g} / \mathrm{g})$, FH-142 $(0.93 \mu \mathrm{g} / \mathrm{g})$, and $\mathrm{MNH}-$ $886(0.56 \mu \mathrm{g} / \mathrm{g})$ (Fig. 1).

The highest concentration of Cry1Ac toxin in the stem was recorded at IR-3701 $(0.4 \mu \mathrm{g} / \mathrm{g})$, followed by FH-Lalazar, FH-142 $(0.2 \mu \mathrm{g} / \mathrm{g})$, and $\mathrm{MNH}-886$ $(0.1 \mu \mathrm{g} / \mathrm{g})$, whereas in roots, none of the selected cultivars showed expression of Cry1Ac protein (Fig. 1).

$\mathrm{Cry} 1 \mathrm{Ac}$ protein was very low in both mature and immature bolls. In mature boll, the highest amount of Cry1Ac protein was recorded in IR-3701 $(0.008 \mu \mathrm{g} / \mathrm{g})$, followed by FH-142 $(0.005 \mu \mathrm{g} / \mathrm{g})$, FH-Lalazar $(0.004 \mu \mathrm{g} / \mathrm{g})$, and MNH-886 $(0.002 \mu \mathrm{g} / \mathrm{g})$ (Fig. 1). Immature bolls had a relatively greater amount of Cry1Ac toxin than that of mature bolls. In immature bolls, the highest concentration of $\mathrm{Cry} 1 \mathrm{Ac}$ toxin was recorded in IR$3701(0.03 \mu \mathrm{g} / \mathrm{g})$, followed by $\mathrm{FH}-142(0.015 \mu \mathrm{g} / \mathrm{g})$, FH-Lalazar $(0.012 \mu \mathrm{g} / \mathrm{g})$, and MNH-886 $(0.010 \mu \mathrm{g} / \mathrm{g})$, (Fig. 1). The highest concentration of Cry1Ac toxin was quantified in the seeds of IR-3701 $(0.68 \mu \mathrm{g} / \mathrm{g})$, followed by FH-Lalazar $(0.66 \mu \mathrm{g} / \mathrm{g}), \mathrm{MNH}-886(0.5 \mu \mathrm{g} / \mathrm{g})$, and FH-142 (0.38 $\mu \mathrm{g} / \mathrm{g})$ (Fig. 1).

\section{Expression of Cry1Ac at different crop stages}

Cry1Ac protein differed concerning different growth stages of the cotton crop. Maximum expression of this protein was quantified at 60 days $(3.37 \mu \mathrm{g} / \mathrm{g})$, after sowing compared to that of 30 days $(2.07 \mu \mathrm{g} / \mathrm{g}), 90(2.17 \mu \mathrm{g} /$ g), and 120 days $(0.92 \mu \mathrm{g} / \mathrm{g})$ (Fig. 2). The highest amount of Cy1Ac toxin quantified after 30 days of sowing was $2.4 \mu \mathrm{g} / \mathrm{g}, 2.3 \mu \mathrm{g} / \mathrm{g}$, and $2.2 \mu \mathrm{g} / \mathrm{g}$, after 60 days of sowing $4.5 \mu \mathrm{g} / \mathrm{g}, 3.8 \mu \mathrm{g} / \mathrm{g}, 3.0 \mu \mathrm{g} / \mathrm{g}$, and $2.2 \mu \mathrm{g} / \mathrm{g}$, while after 120 days post sowing $1.1 \mu \mathrm{g} / \mathrm{g}, 1.1 \mu \mathrm{g} / \mathrm{g}, 0.8 \mu \mathrm{g} / \mathrm{g}$, and $0.7 \mu \mathrm{g} /$ g by FH-142, IR-3701, FH-Lalazar, and MNH-886, respectively. However, after 90 days of sowing, the highest concentration of CrylAc protein was recorded in IR$3701(2.8 \mu \mathrm{g} / \mathrm{g})$, followed by FH-142 $(2.1 \mu \mathrm{g} / \mathrm{g})$, FHLalazar $(1.9 \mu \mathrm{g} / \mathrm{g})$, and MNH-886 (1.5 $\mu \mathrm{g} / \mathrm{g})$ (Fig. 2).

\section{Mortality of targeted larvae}

Mortality of $H$. armigera on transgenic cultivars ranged from 8 to $14 \%$. On IR-3701, mortality was a maximum of $14.0 \%$ compared to $8.00,9.00$, and $10.0 \%$ on $\mathrm{FH}-142$, FH-Lalazar, and MNH-886, respectively (Fig. 3). On FH4243 (Non-Bt cultivar), there was no mortality of $H$. armigera (Fig. 3). The Scatter diagram and trend line revealed a positive linear relationship of Cry1Ac with percentage of mortality because scatter points were distributed very close towards the trend line's positive end. The line further explained that the critical concentration of $\mathrm{Cry} 1 \mathrm{Ac}$ required to kill $50 \%$ of the target

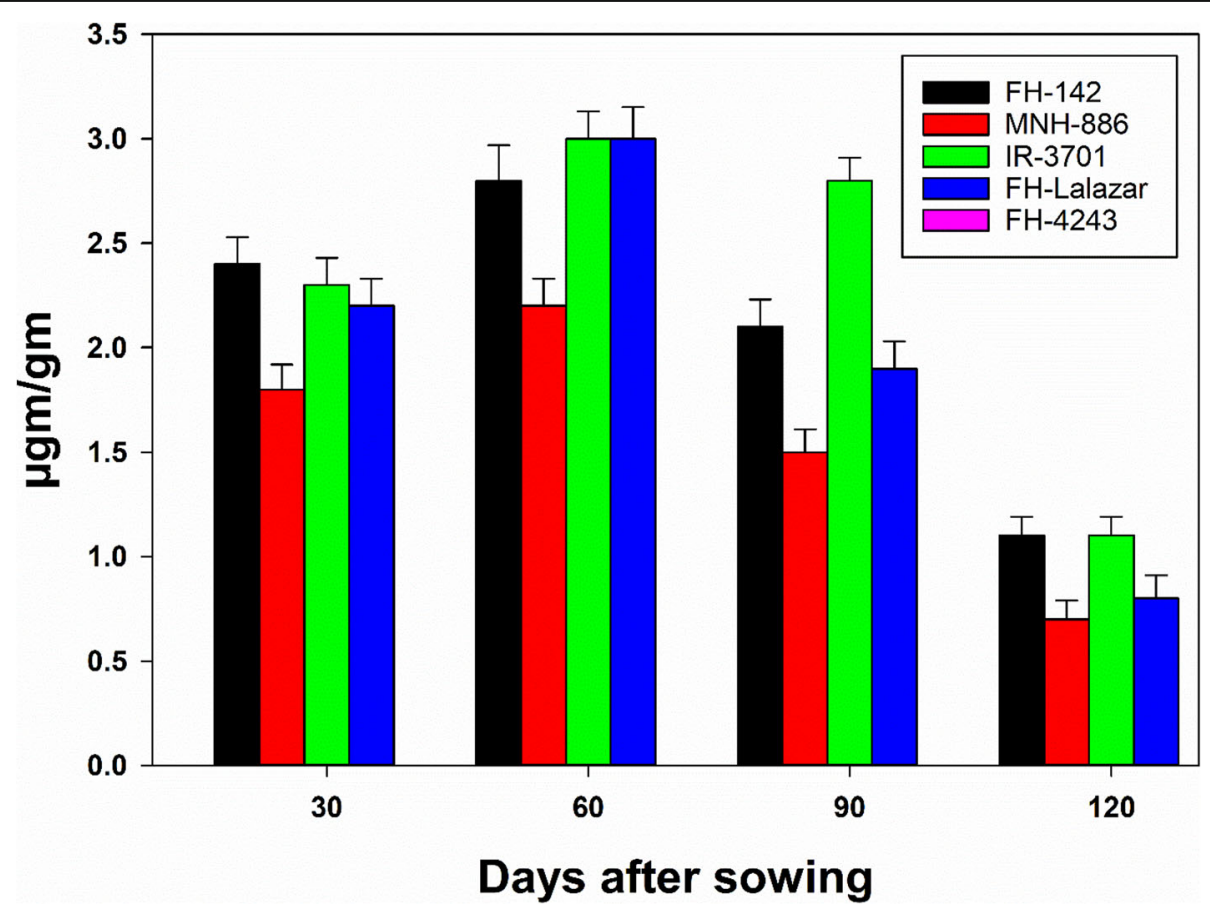

Fig. 2 Bacillus thuringiensis expression of Cry $7 A c(\mu \mathrm{g} / \mathrm{g}$ of fresh wt.) in different cultivars of cotton at different crop stages and time intervals 


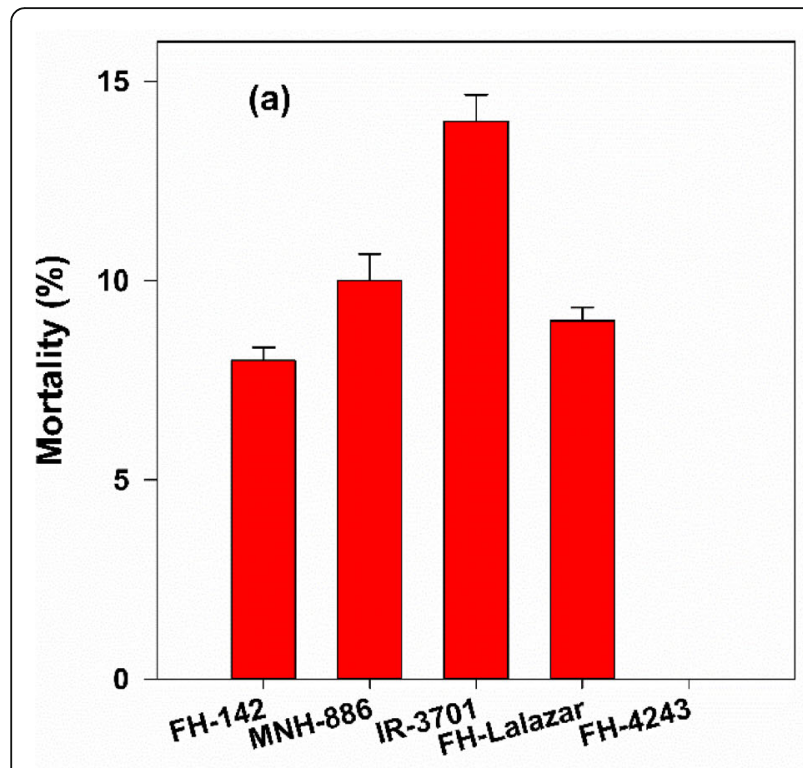

Cultivars

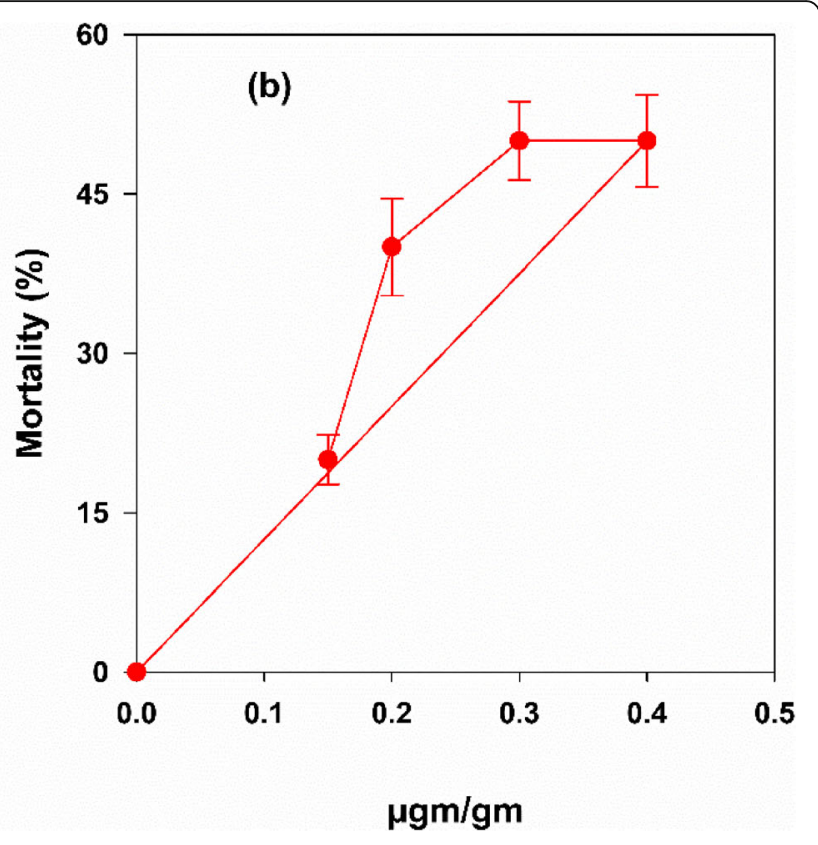

Fig. 3 a Mortality percentage of Helicoverpa armigera by feeding bolls of different cultivars after 90 days of infestation. b Scatter diagram indicating Cry 1 Ac concentrations inducing larval mortality of Helicoverpa armigera larvae of $H$. armigera was $0.3 \mu \mathrm{g} / \mathrm{g}$ of fresh weight (Fig. 3 ). Mortality of $P$. gossypiella due to feeding on the bolls of selected $B t$ cultivars was very negligible. However, it was maximum (1.6\%) on FH-142, followed by MNH-886 and IR-3701 (1.2\%) as compared to $0.4 \%$ on FH-Lalazar and FH-4243 with 0\% mortality (Fig. 4). Expression of
Cry1Ac, i.e., 0.2 to $0.4 \mu \mathrm{g} / \mathrm{g}$ of fresh weight in the reproductive parts of transgenic cultivars of cotton induced only 4.0 to $5.0 \%$ mortality of $P$. gossypiella larvae (Fig. 4). Among selected cultivars, the toxicity of $\mathrm{Cry} 1 \mathrm{Ac}$ to $\mathrm{H}$. armigera was similar (95\% FL overlap). However, the toxicity of IR-3701 was significantly higher than all other

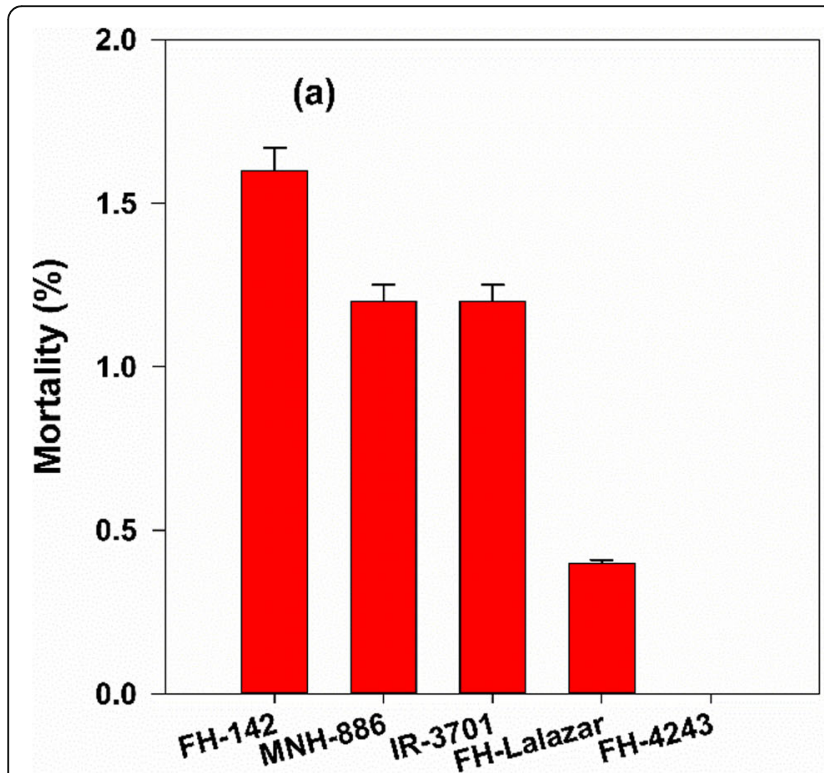

Cultivars

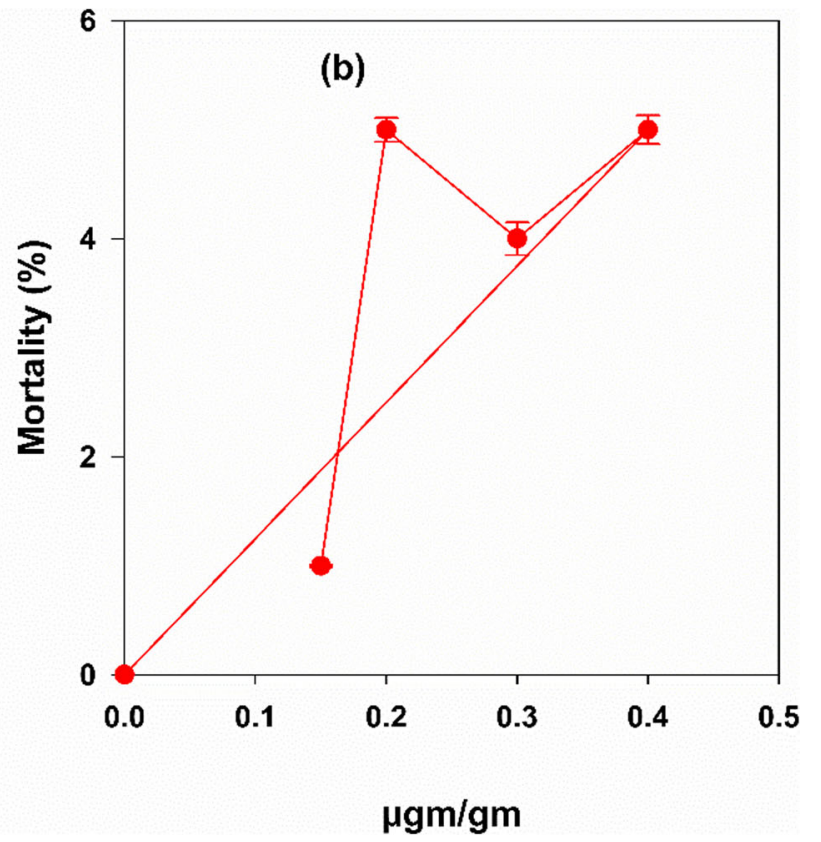

$\mu g m / g m$

Fig. 4 a Mortality percentage of Pectinophora gossypiella by feeding bolls of different cultivars after 90 days of infestation. $\mathbf{b}$ Scatter diagram indicating CrylAc concentrations inducing larval mortality of Pectinophora gossypiella 
cultivars. The toxicity of FH-142 and $\mathrm{MNH}-886$ was almost similar to each other (95\% FL overlap) and was significantly greater than FH-Lalazar. Among cultivars, the toxicity of Cry1Ac to $P$. gossypiella was significantly different from each other (95\% FL overlap). The toxicity of Cry1Ac in MNH-886 and IR-3701 was similar but was significantly higher than FH-Lalazar; however, the maximum toxic effect of Cry1Ac was observed by FH-142 (Table 1).

\section{Discussion}

The present study results demonstrated that the highest expression of the Cry1Ac protein was recorded in the upper leaves of tested cultivars compared to the other plant parts, followed by middle and lower leaves. Medium expression was displayed in stem and floral parts by the Cry1Ac protein, whereas the least or negligible expression was recorded in bolls and roots. In selected cultivars, $\mathrm{Cry} 1 \mathrm{Ac}$ concentration ranged from $2.50-3.39,2.17-2.91$, and $1.32-1.62 \mu \mathrm{g} / \mathrm{g}$ in upper, middle, and lower leaves, respectively. Results further exhibited that after 90 days of sowing, the $B t$ expression was maximum, however in the upper canopy, leaves expression was maximum than the middle and lower canopy leaves. Maximum $B t$ expression was reported at the seedling/young leaf stage that gradually decreased. Kranthi et al. (2005) reported the reason of this phenomenon that $B t$ crystalline proteins in old leaves were denatured.

Results further exhibited that Bt concentration $(3.39 \mu \mathrm{g} / \mathrm{g})$ in leaves of selected cultivars was very higher than the flower (1.8), seeds (0.8), stem, and roots $(0.4 \mu \mathrm{g} /$ g). Mortality of $P$. gossypiella comparatively was less than $H$. armigera might be due to the monophagous/ polyphagous feeding nature and spatio-temporal expression of $B t$ protein. $H$. armigera fed on the leaves that contained higher concentration of Cry1Ac than reproductive parts and are killed at the initial stage. However, larvae of $P$. gossypiella very soon after their hatching from the eggs enter into the flower and bolls that possess less concentration of Cry1Ac than leaves might survive. The field evolved resistance had earlier been reported in P. gossypiella by Dhurua and Gujar (2011). They observed more susceptibility of these insects against Bollgard-II populations because of high concentration (15.4 $\mathrm{ng} \mathrm{mg}^{-2}$ ) of Cry2Ab2 proteinthan $(0.005 \mathrm{ng}$ $\mathrm{mg}^{-2}$ ) Cry1Ac.

Due to continuous exposure of $B t$ cotton, different levels of toxicities of $C r y 1 A c$ against a population of lepidopterous larvae have been observed. These differences in toxicities against mortality gave us a clue that $H$. armigera and $P$. gossypiella posed varying resistance levels against $B t$. $\mathrm{LC}_{50}$ values ranged from 8.91 to 36.4 and 2.37 to $8.26 \mathrm{ppm}$ for P. gossypiella and H. armigera, respectively. It is also clear from the results that the resistance problem was more in $P$. gossypiella than $H$. armigera. The field evolved resistance in lepidopteran larvae to Bt Cry1Ac was reported by Tabashnik et al. (2013). Kranthi et al. (2005) identified a critical expression level of $1.9 \mu \mathrm{g} / \mathrm{g}$ for mortality of $H$. armigera below which this insect will develop resistance, furthermore feeding larvae can develop a high degree of resistance against Cry1Ac. Tabashnik et al. (2013) also reported that laboratory-selected pink bollworm population showed up to 420 -fold cross-resistance to Cry $1 \mathrm{Ac}$ and 240-fold resistance to Cry2Ab.

To impede the threat of $B t$ resistance in lepidopteran larvae, the production of $B t$ plants are required to ensure the guaranteed mortality of the target larvae, with concentrations high enough $\left(\mathrm{LD}_{99}\right)$. Better is to provide a susceptible population of $H$. armigera by cultivation of refuge crop strategy. Refuge crop limits the intensity of

Table 1 Median lethal concentration of Bacillus thuringiensis protein against the target insect pest species

\begin{tabular}{|c|c|c|c|c|c|c|c|}
\hline Target larvae & Variety & $\mathrm{LC}_{50}^{\mathrm{a}}(\mathrm{ppm})^{\mathrm{b}}$ & $95 \% \mathrm{FL}^{\mathrm{c}}$ & Slope $\left( \pm \mathrm{SE}^{\mathrm{d}}\right)$ & $x^{2 \mathrm{e}}$ & $\mathrm{df}^{f}$ & $P^{g}$ \\
\hline \multirow[t]{4}{*}{ Pectinophora gossypiella } & FH-142 & 8.91 & $4.16-12.2$ & $0.6( \pm 0.21)$ & 1.45 & 3 & 0.83 \\
\hline & MNH-886 & 13.4 & $6.21-20.7$ & $0.76( \pm 0.49)$ & 0.46 & 3 & 0.92 \\
\hline & IR-3701 & 14.0 & $3.20-25.3$ & $0.70( \pm 0.43)$ & 0.87 & 3 & 0.83 \\
\hline & FH-Lalazar & 36.4 & $22.04-50.7$ & $0.65( \pm 0.2)$ & 0.39 & 3 & 0.94 \\
\hline \multirow[t]{4}{*}{ Helicoverpa armigera } & FH-142 & 5.91 & $3.26-7.2$ & $0.8( \pm 0.41)$ & 0.45 & 3 & 0.93 \\
\hline & MNH-886 & 4.04 & $1.23-7.2$ & $0.52( \pm 0.22)$ & 0.34 & 3 & 0.95 \\
\hline & IR-3701 & 2.37 & $0.15-4.8$ & $1.47( \pm 0.17)$ & 3.94 & 3 & 0.27 \\
\hline & FH-Lalazar & 8.26 & $4.18-12.35$ & $0.5 \pm(0.25)$ & 0.08 & 3 & 0.97 \\
\hline
\end{tabular}

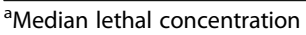

${ }^{b}$ Parts per million

'Fiducial limit

${ }^{\mathrm{d}}$ Standard error

${ }^{\mathrm{e}} \mathrm{Chi}$-square

fDegree of freedom

9Probability

${ }^{\mathrm{h}}$ Total number of insects tested in each bioassay 
selection on the target pest and enhances the life span of $B t$ cotton/ transgenic technology. In the USA, the cultivation of refuge crop has been strictly supervised, where the compliance rate has been calculated $82 \%$. In Australia, farmers have chosen to be among the 5 choices for refuge (conventional cotton spraying, unprayed traditional cotton, sorghum, maize, or pigeon pea in different areas as defined by the relative productivity of the refuge. In the same way, in South Africa, mono transgenic event containing the cry $1 \mathrm{Ab}$ protein for regulation of maize stem borer $(H$. armigera) has been commercialized with stipulated requirement for the establishment of a 20\% refuge crop. Frequency of cases of evolution of resistance is very high in the countries where non-Bt refuge has been ignored by the growers.

$H$. armigera fed on a variety of host plants. There was a less chance of field evolved resistance against $B t$ cotton compared to $P$. gossypiella being monophagous and having a great potential to evolve resistance against Cry1Ac. Farmers may be advised to follow the practice of growing non- $B t$ as refuge crops to reduce the problem of field evolved resistance in the target arthropod species. Refuge crop was very useful, and the same practice has been practiced in other countries of the world to manage field evolved resistance in lepidopterous insect species against $B t$ cotton. Wan et al. (2012) also suggested that non- $B t$ cotton as a refuge crop should be cultivated on a large scale and integrated with $B t$ cotton as a management tactic.

\section{Conclusion}

Based on the results, the increase in concentration of $B t$ protein will induce $B t$ resistance problem. It was notable that in top leaves, Cry1Ac expression was maximum than in other plant parts. Larval mortality in $H$. armigera was higher than $P$. gossypiella in selected $B t$ cultivars due to its polyphagous feeding nature. $\mathrm{LC}_{50}$ value depicted that there was more $B t$ resistance in the tested population of $P$. gossypiella than of $H$. armigera larvae. It can be suggested that growing of non- $B t$ as refuge crop will be very useful to minimize $B t$ resistance problem in P. gossypiella.

\section{Abbreviations}

Bt: Bacillus thuringiensis; LC: Lethal concentration; ELISA: Enzyme-linked immunosorbent assay; US: United States; RCBD: Randomized Complete Block Design; Ppm: Parts per million; R.H.: Relative humidity; ANOVA: Analysis of variance; HSD: Honestly significant difference; FL: Fiducial limit

\section{Acknowledgements}

I acknowledge the cooperation of Muhammad Riaz field staff of the institute, who helped me in the allocation of treatments/varieties.

\section{Authors' contributions}

MRF and MF designed and performed the experiments. MS, MA, and ZUZ helped in the data analysis and manuscript writeup. SA and AM supervised the whole experiments and reviewed the early draft of the manuscript. All authors have read and approved the manuscript.

\section{Funding}

The studies were carried out with the assistance of the annual budget allocated to Cotton Research Institute, Multan, Pakistan, from the Government of the Punjab, Pakistan.

\section{Availability of data and materials}

The datasets used and/or analyzed during the current study are available from the corresponding author on reasonable request.

Ethics approval and consent to participate

Not applicable

Consent for publication

Not applicable

\section{Competing interests}

There is no conflict of interest

\section{Author details}

${ }^{1}$ Cotton Research Institute, Multan, Pakistan. ${ }^{2}$ School of Earth, Environment and Biological Sciences, Queensland University of Technology, Brisbane 4000, Australia. ${ }^{3}$ Key Laboratory of Bio-Pesticide Innovation and Application of Guangdong Province, College of Plant Protection, South China Agricultural University, Guangzhou, China. ${ }^{4}$ Entomological Research Institute, Ayub Agricultural Research Institute, Faisalabad, Pakistan. ${ }^{5}$ Punjab Agriculture Research Board, Lahore, Pakistan.

Received: 30 November 2020 Accepted: 12 February 2021

Published online: 19 February 2021

\section{References}

Ali S, Rana A, Zia MA, Khan SU, labal A, Ali GM (2018) Temporal status of Bt gene expression in Pakistani cotton. Pakistan J Agric Sci 55(1):143-150

Dhurua S, Gujar GT (2011) Field-evolved resistance to Bt toxin CrylAc in the pink bollworm, Pectinophora gossypiella (Saunders)(Lepidoptera: Gelechiidae), from India. Pest Management Science 67:898-903

Duan H, Ding X, Song J, Duan Z, Zhou Y, Zhou C (2009) Effects of kanamycin on growth and development of Arabidopsis thaliana seedling, cotyledon and leaf. Pakistan J Botany 41(4):1611-1618

Huang J, Wang X, Dang H (2017) Impacts of and attitudes toward G technology in China: challenges, policy and research implications. Chin Agric Econ Rev 9: 334-339

Jin L, Zhang H, Lu Y, Yang Y, Wu K, Tabashnik BE, Wu Y (2015) Large-scale test of the natural refuge strategy for delaying insect resistance to transgenic $\mathrm{Bt}$ crops. Nature Biotechnology 33:169-174

Kranthi KR, Naidu S, Dhawad C, Tatwawadi A, Mate K, Patil E, Bharose A, Behere G, Wadaskar R, Kranthi S (2005) Temporal and intra-plant variability of CrylAC expression in Bt-cotton and its influence on the survival of the cotton bollworm, Helicoverpa armigera (Hübner)(Noctuidae: Lepidoptera). Curr Sci 89:291-298

Mapuranga R, Chapepa B, Mudada N (2015) Strategies for integrated management of cotton bollworm complex in Zimbabwe: a review. Int J Agronomy Agric Res 7:23-35

Olsen K, Daly J, Holt H, Finnegan E (2005) Season-long variation in expression of CryIAc protein and efficacy of Bacillus thuringiensis toxin in transgenic cotton against Helicoverpa armigera (Lepidoptera: Noctuidae). J Econ Entomol 98: 1007-1017

Pogue MG (2004) A new synonym of Helicoverpa zea (Boddie) and differentiation of adult males of $\mathrm{H}$. zea and $\mathrm{H}$. armigera (Hübner) (Lepidoptera: Noctuidae: Heliothinae). Ann Entomol Soc Am 97:1222-1226

Pratissoli D, Lima VL, Pirovani VD, Lima WL (2015) Occurrence of Helicoverpa armigera (Lepidoptera: Noctuidae) on tomato in the Espírito Santo state. Horticultura Brasileira 33:101-105

Sansinenea E (2019) Applications and patents of Bacillus spp. in agriculture. In: Singh HB, Keswani C, Singh SP (eds) Intellectual Property Issues in Microbiology, pp 133-146 
Shah MA, Farooq M, Shahzad M, Hussain M (2017) Yield and phenological responses of bt cotton to different sowing dates in semi-arid climate. Pakistan J Agric Sci 54(2):233-237

Shahid MR, Shakeel M, Farooq M, Arain MS, Hanif CMS, Yin H, Akram M, Ahmad S

(2017) Earliness index deter Pectinophora gossypiella incidence on advanced cultivars of Bt cotton. Arthropod-Plant Interactions 12:303-309

Stewart S, Adamczyk J, Knighten K, Davis F (2001) Impact of Bt cottons expressing one or two insecticidal proteins of Bacillus thuringiensis Berliner on growth and survival of noctuid (Lepidoptera) larvae. J Econ Entomol 94: 752-760

Tabashnik BE, Brevault T, Carriere Y (2013) Insect resistance to Bt crops: lessons from the first billion acres. Nature Biotechnology 31:510-521

Wan P, Huang Y, Wu H, Huang M, Cong S (2012) Increased frequency of pink bollworm resistance to Bt toxin Cry1Ac in China. PLoS ONE 7:e29975. https:// doi.org/10.1371/journal.pone.0029975

Wrather JA, Shannon JG, Carter TE, Bond JP, Rupe JC, Almeida AMR (2008) Reaction of drought-tolerant soybean genotypes to Macrophomina phaseolina. Plant Health Progress 9(1):16

Wu K, Mu W, Liang G, Guo Y (2005) Regional reversion of insecticide resistance in Helicoverpa armigera (Lepidoptera: Noctuidae) is associated with the use of Bt cotton in northern China. Pest Management Science 61:491-498

\section{Publisher's Note}

Springer Nature remains neutral with regard to jurisdictional claims in published maps and institutional affiliations.

\section{Submit your manuscript to a SpringerOpen ${ }^{\circ}$ journal and benefit from:}

- Convenient online submission

- Rigorous peer review

- Open access: articles freely available online

- High visibility within the field

- Retaining the copyright to your article

Submit your next manuscript at $\boldsymbol{\nabla}$ springeropen.com 